\title{
Short communication: Seagrass diversity and carbon sequestration: Case study on Pari Island, Jakarta Bay, Indonesia
}

\author{
TEGUH HUSODO ${ }^{1,2,3}$, SAHBUDDIN DG. PALABBI ${ }^{2}$, OEKAN S. ABDOELLAH ${ }^{2,3}$, MOHAMAD NURZAMAN ${ }^{1}$, \\ NURULLIA FITRIANI ${ }^{1}$, RUHYAT PARTASASMITA ${ }^{1, \bullet}$ \\ 1Biology Department, Math and Science Faculty, Universitas Padjadjaran. Jl. Raya Jatinangor KM 21, Sumedang 45363, West java, Indonesia. Tel./fax.: \\ +62-22-7796412. `email: ruhyat.partasasmita@unpad.ac.id \\ ${ }^{2}$ Programe of Environmental Science, School of Graduates, Universitas Padjadjaran. Jl. Sekeloa, Coblong, Bandung 40134, West Java, Indonesia. \\ ${ }^{3}$ Institute of Ecology, Directorate of Reseach, Community Services and Innovation, Universitas Padjadjaran. Jl. Sekeloa, Coblong, Bandung 40134, West \\ Java, Indonesia
}

Manuscript received: 5 July 2016. Revision accepted: 10 October 2017.

\begin{abstract}
Husodo T, Palabbi SDG, Abdoellah OS, Nurzaman M, Fitriani N, Partasasmita P. 2017. Seagrass diversity and carbon sequestration: Case study on Pari Island, Jakarta Bay, Indonesia. Biodiversitas 18: 1596-1601. Pari Island is located in Kepulauan Seribu chain. As a tourist destination, the seagrass ecosystem at the island is constantly under pressure from time to time. An effort to prevent widespread damage is to designate parts of the coastline as a limited access research centre. Efforts to study seagrass ecosystem on Pari Island are ongoing, including studies on seagrass' ability to sequestrate carbon. This quantitative study was conducted in December 2014. Surveys are done on the abundance and density of seagrass in 122 plots $\left(\right.$ area $\left.=50 \times 50 \mathrm{~cm}^{2}\right)$ which spread in 6 research stations. Biomass measurements were performed by extractive method on 4 types of seagrass (Cymodocea serrulata, Halophila ovalis, Halodule uninervis and Syringodium isoetifolium). The assessment of seagrass capability in storing carbon has been done by measuring the primary productivity of above ground and below ground, while the amount of carbon released is measured from littered leaves and the leaves eaten by herbivores.The findings show that there are 7 of 12 species of seagrass identified in Indonesia, i.e. Cymodoceae rotundata, Cymodoceae serrulata, Thalassia hemprichii, Enhalus acoroides, Syringodium isoetifolium, Halodule uninervis and Halophila ovalis. The dominant species is Thalassia hemprichii (density $200 \pm 153,261 \pm 107$ and $117 \pm 52 \mathrm{stands} / \mathrm{m}^{2}$ ) and Halodule uninervis $\left(82 \pm 59\right.$ stands $\left./ \mathrm{m}^{2}\right)$.Seagrass' carbon sequestration capacity in the waters surrounding Pari Island, Jakarta Bay, is approximately $0.006-1.048 \mathrm{gC} / \mathrm{m}^{2} /$ day whereas carbon reserves are between $0.24-346.10 \mathrm{gC} / \mathrm{m}^{2}$.
\end{abstract}

Keywords: Carbon sequestration, carbon reserve seagrass ecosystem, Jakarta Bay, Pari Island

\section{INTRODUCTION}

The seagrass ecosystem is a coastal ecosystem like coral reefs and mangrove. The ecosystem is facing sustained damages in terms of quality and coverage. The Indonesian seagrass ecosystem covers some $30,000 \mathrm{~km}^{2}$, although the area is believed to have been reduced by 30 $40 \%$. The Pari Island's seagrass ecosystem in DKI Jakarta has diminished by 25\% between 1999 and 2004. A number of factors, such as reclamation and physical developments along coastlines, pollution, and blast and cyanide fishing, are the cause of degradation and shrinking of the ecosystem. In the case of Pari Island, Kiswara (1999) found that seagrass damage is caused by water whirlpool due to the fishing boats' propellers and tourism activities.

Quality of the ecosystem can be assessed, among others, by the species abundance and species distribution that expressed interaction of abiotic (chemical and physical) and biotic components (Pearson and Rosenberg 1978). Similarly in the distribution and abundance of seagrass species, it is influenced by salinity, temperature, tidal and muddy substrate or muddy sand (Hemminga and Duarte 2000). The seagrass ecosystem has many functions, such as a habitat of the coastal aquatic organisms, and a regulator of pollutants and carbon (Liberatus 2016). Fourqurean et al. (2012) explain that seagrass could store up to 83,000 metric tons of carbon per $\mathrm{km}^{2}$ or can save twice as much as forest. It is estimated that the seagrass ecosystem is able to sequestrate $10 \%$ of the total carbon received by the oceans each year.

The study of potential seagrass as carbon storage and carbon sequestration have been carried out at various coastal waters locations on Indonesia, such as on the coastal waters of Pari Island at Jakarta Bay by Kiswara (2010) from the Oceanography Research Center (The Indonesian Institute of Sciences) especially for species of Enhalus acoroides, Cymodocea rotundata and Thalassia hemprichii. Rahmawati and Kiswara (2012) have continued Enhalus acoroides research in sequestrating, releasing and storing carbon. Study at the community level has been done by Rahmawati (2011). A similar study has also been conducted in Barrang Lompo Island Makassar (Supriya 2014) and Banten bay Waters (Rustam 2016), but both did not measure the ability of carbon storage which was assessed by the difference between the amount of carbon absorbed and the amount of carbon released.

Based on the findings in Kiswara (2010) and Rahmawati (2011) researches, the research on carbon 
storage capability in seagrass ecosystems on the coastal waters of Pari Island might be used as a reference for similar studies in other coastal waters in Indonesia. Referring to the research that has been conducted in Pari Island, this study answers the following questions : a) what are the species, abundance, and density of seagrass ecosystem at Pari Island; b) how much the carbon sequestration capacity $\left(\mathrm{gC} / \mathrm{m}^{2} /\right.$ day $)$ of the 4 selected seagrass species (Cymodocea serrulata, Halophila ovalis, Halodule uninervis and Syringodium isoetifolium) in the waters surrounding Pari Island, Jakarta Bay; and, c) how much carbon is stored $\left(\mathrm{gC} / \mathrm{m}^{2}\right)$ in those 4 selected seagrass species in the waters surrounding Pari Island, Jakarta Bay.

\section{MATERIALS AND METHOD}

\section{Study area}

This study was conducted in December 2014 in seagrass communities in waters surrounding Pari Island, Jakarta Bay. Surveys are done on the abundance and density of seagrass in 122 plots $\left(\right.$ size $\left.=50 \times 50 \mathrm{~cm}^{2}\right)$ spreading across 6 research stations.

\section{Procedure}

Quantitative method is used in this study, and data collection is done by survey using 122 square plots technique $(50 \mathrm{x} 50 \mathrm{~cm})$ along imaginary transects. Transects for data collection (composition, abundance and density of seagrasses) were placed on 6 stations, namely, North Station I (20 plots); North Station II (14 plots), West Station (10 plots), South Station I (21 plots), South Station II (27 plots), and South Station III (30 plots). Carbon sequestration capacity was measured from four species of seagrass (Cymodocea serrulata, Halophila ovalis, Halodule uninervis and Syringodium isoetifolium) which were found only at the South Station. Parameters taken at each station were the percentage of seagrass covering using visual estimation method based on the SeagrassWatch Standard Guidance for Seagrass Covering (McKenzie et al. 2003) (Figure 1).

\section{Data analysis}

Species identification was done by following method of Husni (1999). Seagrass abundance and density were calculated using the Seagrass Watch Standard (McKenzie et al. 2003, English et al 1997). The carbon storage and carbon sequestration measurements were conducted using the approach of density, biomass and carbon content (\% C) relationship in different organs of seagrass plants by Rahmawati and Kiswara's (2012) method and its conversion into organic carbon used the Walkley and Black's methods (Schumaker 2002).

\section{RESULTS AND DISCUSSION}

\section{Seagrass structure}

In general, the seagrass community on Pari Island was composed by two or more species, except in the western coast (West Station/A) where only one species was found. Of the seven species recorded in this study, Thalassia hemprichii (Sum Dominance Ratio/SDR $=25.5 \%$ ) and Enhalus acoroides (SDR $=58.4 \%$ ) were the most dominant. Seagrass species was distributed across the sampling plots (total $=122$ ) at six research stations. Enhalus acoroides was found in every research station and Thalassia hemprichii was found in four research stations. On the other hand, other seagrass species (Cymodocea rotundata, Cymodocea serrulata, Halodule uninervis, Halophila ovalis, and Syringodium isoetifolium) were only found in a few plots at the southern coast of Pari Island (South Station/B) (Figure 1).

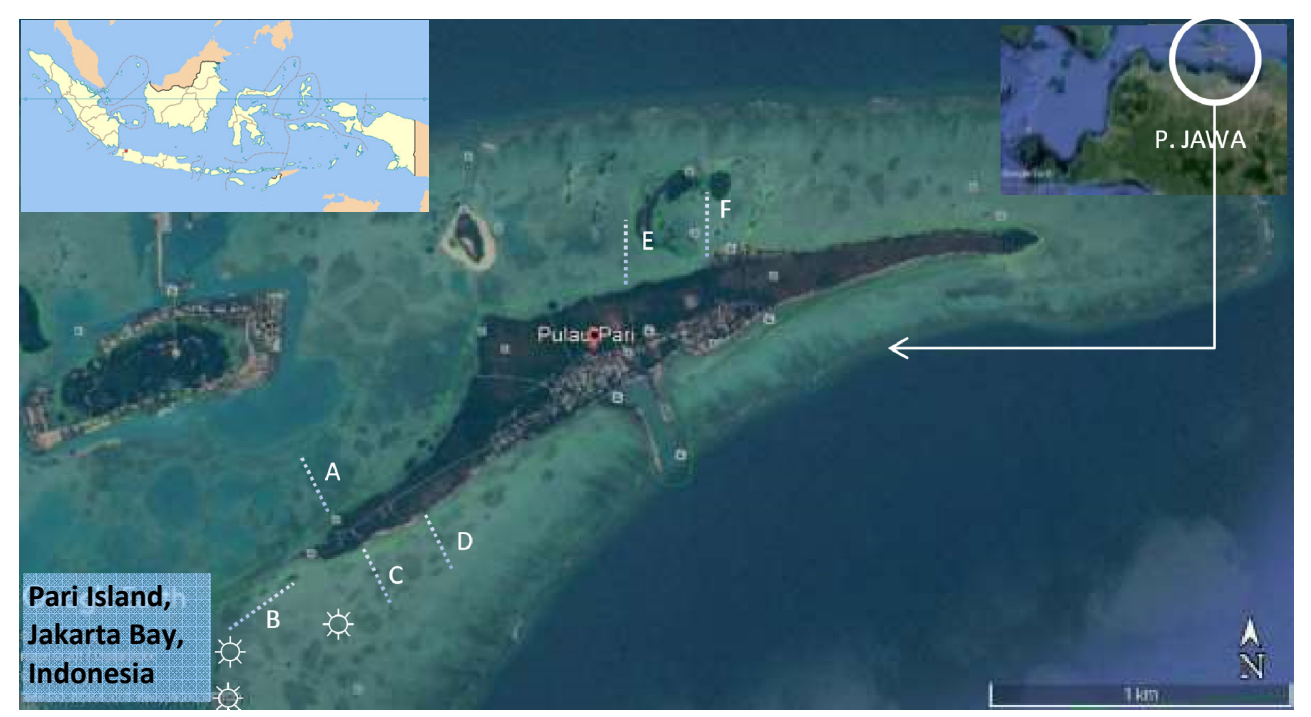

Figure 1. Location map in the coastal waters of Pari Island, Jakarta Bay, Indonesia. A. West Station, C-D. South Station, and E-F. North Station. The black dotted line is a square plot transects to show the plot location for density and biomass sampling. The sign ( $\$$ ) indicates the location of leaf growth measurement and seagrass litter traps for calculation of carbon sequestration capability 
The seagrass covering in plot area referred to Rahmawati (2011), the average of seagrass covering on Southern Beach and Western Coast was $22.86 \%$ and $23.17 \%$. For the seagrass covering at Northern Coast with the range from $21.50 \%$ to $30.50 \%$ referred to Kiswara's method (2010). From the result from these four locations, it can be concluded that the highest seagrass density recorded at South Station I with $261 \pm 107$ stands $/ \mathrm{m}^{2}$ was Thalassia hemprichii, while the lowest density of seagrass recorded at South Station II with $22 \pm 3$ stands $/ \mathrm{m}^{2}$ was Enhalus acoroides (Figure 2). The same picture showed that the seagrass species at each study site had different density values, for example Enhalus acoroides at North Station II and West Station ranging from $67 \pm 28 \mathrm{stands} / \mathrm{m}^{2}$ and $62 \pm 28$ stands $/ \mathrm{m}^{2}$. This value was lower than the average density in some other smaller seagrass species found in the southern part of Pari Island, such as Cymodocea serrulata $(84 \pm 34$ stands $\left./ \mathrm{m}^{2}\right)$, Halodule uninervis $\left(82 \pm 59\right.$ stands $\left./ \mathrm{m}^{2}\right)$, Syringodium isoetifolium $\left(118 \pm 71 \quad\right.$ stands $\left./ \mathrm{m}^{2}\right)$ and Halophila ovalis $\left(67 \pm 12\right.$ stands $\left./ \mathrm{m}^{2}\right)$ at South Station III. The data indicated that seagrass density per unit area was highly dependent on species covering it. Nienhuis et al. (1989) noted that seagrasses with large morphological features, such as Enhalus acoroides, tended to have lower coverage density compared to those with smaller morphological features such as Halodule uninervis.

\section{Seagrass biomass}

Seagrass biomass is closely related with the size of seagrass' morphological features. Seagrass with large morphological features, such as Enhalus acoroides, has higher biomass values compared to those with smaller morphological features, such as Halophila ovalis. Biomass of the seagrass are shown in Table 1. The highest seagrass biomass average was found in North Station II $\left(772.65 \pm 461.85 \mathrm{gBK} / \mathrm{m}^{2}\right)$ and West Station $(536.46 \pm 275.68$ $\left.\mathrm{gBK} / \mathrm{m}^{2}\right)$, largely populated by Enhalus acoroides. The lowest seagrass biomass average was found in South Station III $\left(1.05 \pm 0.42 \mathrm{gBK} / \mathrm{m}^{2}\right)$, largely populated by Halophila ovalis. The findings in the western coast were consistent with Rahmawati (2011) that the dominant Enhalus acoroides population resulted in larger biomass values than that in the mixed population at southern coast.

Biomass value is closely linked with extracted parts of seagrass to calculate its overall biomass. Seagrass rhizome was part of the seagrass with the highest biomass value (361.11 $\pm 196.53 \mathrm{gBK} / \mathrm{m} 2$ for Enhalus acoroides) and the lowest was $0.14 \pm 0.04 \mathrm{gBK} / \mathrm{m} 2$. Similarly, for Halophila ovalis, the highest was $0.45 \pm 0.28 \mathrm{gBK} / \mathrm{m} 2$ and the lowest was $0.32 \pm 0.16 \mathrm{gBK} / \mathrm{m} 2$ compared with biomass of its shoot (lamina and bract) of the same species $(265.97 \pm 167.01 \mathrm{gBK} / \mathrm{m} 2$ and $36.11 \pm 27 \mathrm{gBK} / \mathrm{m} 2)$ for Enhalus acoroides, while for Halophila ovalis the highest was $0.5 \pm 0.44 \mathrm{gBK} / \mathrm{m} 2$ and the lowest was $0.33 \pm 0.13$ $\mathrm{gBK} / \mathrm{m} 2$. Similar findings were found in Kiswara's research (2010) that the average biomass of seagrass rhizome is higher than other parts of the plant. Nienhuis et al. (1989) reported that the biomass of seagrass lower parts (roots and rhizomes) are six to ten times greater than the upper parts (bract and lamina).
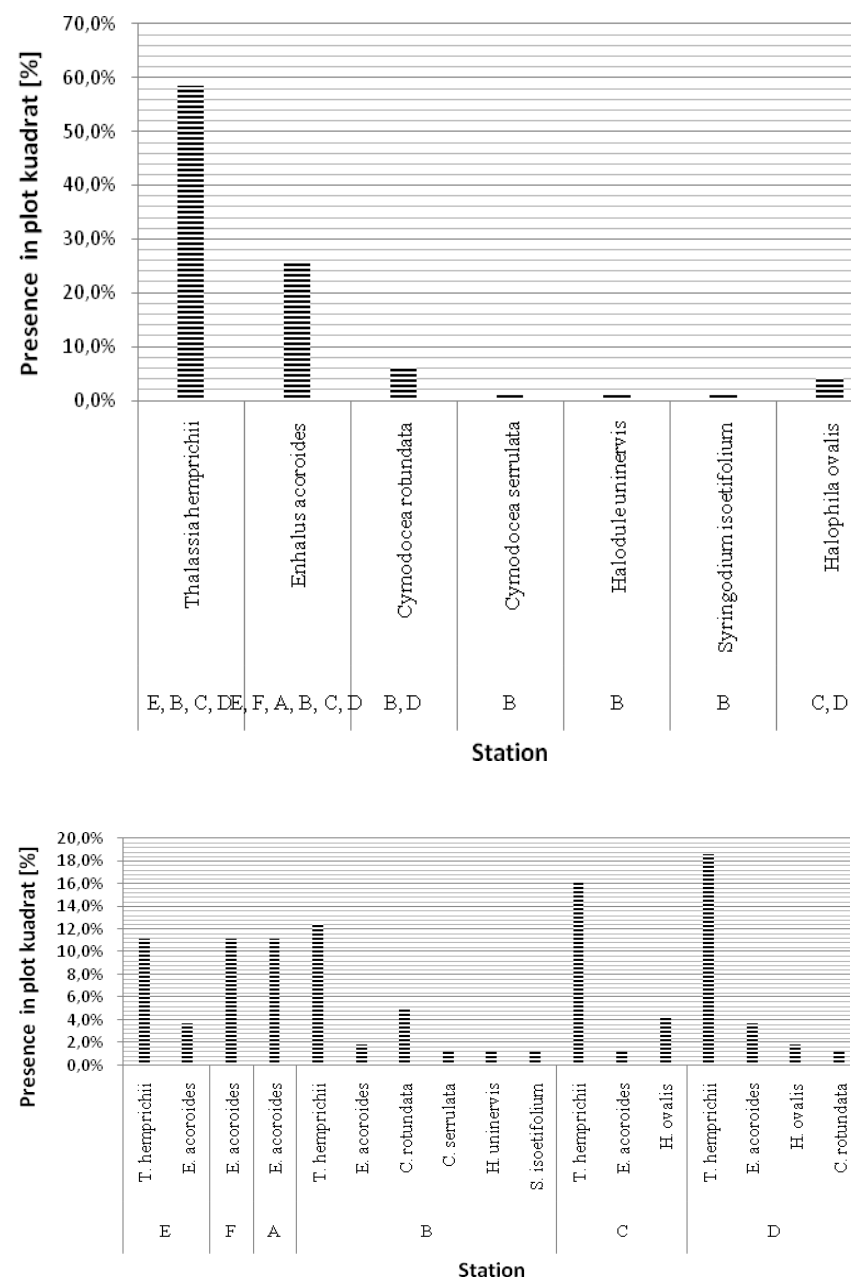

Figure 1. Abundance (in \%) of seagrass species at any location / station in the coastal waters of Pari Island. West Station (A); South Station (C, D) and North Station (E, F)

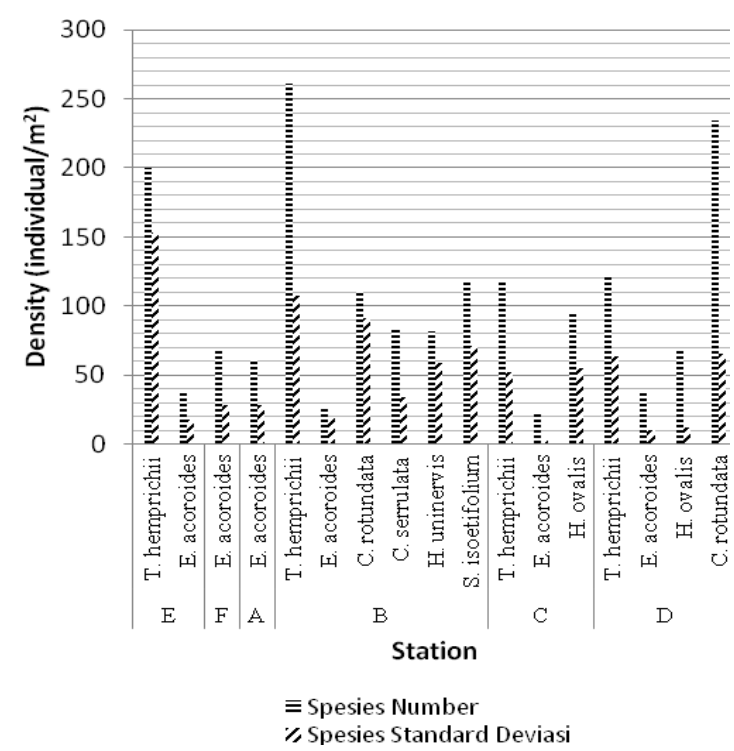

Figure 2. Density $\left(\operatorname{stand} / \mathrm{m}^{2}\right.$ ) at each location/station on Pari Island coastal waters. West Station (A); South Station (C, D) and North Station (E, F) 


\section{Seagrass carbon sequestration capacity}

Carbon sequestrated via photosynthesis process is stored and distributed into the seagrass compartments, among others, in its biomass both above and below the substrate. Since carbon stored in biomass, particularly in below the substrate part of plants, it will be kept for long periods of time. This made the long-term role of seagrass in carbon sequestration is important (Kiswara and Ulumuddin 2009). Based on carbon storage capacity calculations, measured by the amount of carbon captured (from primary productivity above and below ground) and released (from leaf litter and consumption by herbivores), seagrass in coastal waters surrounding Pari Island is able to store from 0.007 to $1.825 \mathrm{gC} / \mathrm{m}^{2} /$ day while releasing only 0.001 to $0.777 \mathrm{gC} / \mathrm{m}^{2} /$ day (Table 2). The overall capacity of the seven species of seagrass is between 0.006 and 1.048 $\mathrm{gC} / \mathrm{m}^{2} /$ day.

Table 1. Species composition and seagrass Bbomass research area Pari Island in Jakarta Bay, Indonesia

\begin{tabular}{|c|c|c|c|c|c|c|c|c|}
\hline \multirow[b]{2}{*}{ Station } & \multirow[b]{2}{*}{ Species } & \multirow[b]{2}{*}{$\begin{array}{c}\text { Number of } \\
\text { plot }\end{array}$} & \multirow[b]{2}{*}{ Par. } & \multicolumn{4}{|c|}{ Seagrass biomassa $\left(\mathrm{gBK} / \mathrm{m}^{2}\right)$} & \multirow{2}{*}{$\begin{array}{r}\text { Total of } \\
\text { biomassa } \\
\left(\mathrm{gBK} / \mathrm{m}^{2}\right)\end{array}$} \\
\hline & & & & $\begin{array}{c}\text { Leaf } \\
\text { strand }\end{array}$ & $\begin{array}{l}\text { Leaf } \\
\text { base }\end{array}$ & Stem & Root & \\
\hline \multirow{4}{*}{$\begin{array}{l}\text { North } 1 \\
(\mathrm{~N}=20)\end{array}$} & T. hemprichii & 18 & $\mathrm{X}$ & 44.33 & 56.99 & 76.85 & 51.80 & 229.96 \\
\hline & $(n=18)$ & & Sd & 44.09 & 49.33 & 76.22 & 45.70 & 215.34 \\
\hline & E. acoroides & 6 & $X$ & 77.40 & 33.18 & 189.99 & 61.04 & 361.61 \\
\hline & $(n=6)$ & & $\mathrm{Sd}$ & 60.65 & 17.11 & 151.95 & 37.61 & 267.32 \\
\hline \multirow{4}{*}{$\begin{array}{l}\text { North } 2 \\
(\mathrm{~N}=14) \\
\text { West } \\
(\mathrm{N}=10)\end{array}$} & E. acoroides & 14 & $\mathrm{X}$ & 265.97 & 71.47 & 361.11 & 74.09 & 772.65 \\
\hline & $(n=14)$ & & $\mathrm{Sd}$ & 167.01 & 53.69 & 196.53 & 44.61 & 461.85 \\
\hline & E. acoroides & 10 & $\mathrm{X}$ & 195.39 & 50.99 & 233.02 & 57.06 & 536.46 \\
\hline & $(n=10)$ & & $\mathrm{Sd}$ & 96.48 & 23.97 & 118.77 & 36.47 & 275.68 \\
\hline \multirow{12}{*}{$\begin{array}{l}\text { South } 1 \\
(\mathrm{~N}=22)\end{array}$} & T. hemprichii & 20 & $X$ & 33.35 & 45.38 & 65.68 & 21.95 & 166.37 \\
\hline & $(n=20)$ & & $\mathrm{Sd}$ & 30.98 & 37.51 & 57.68 & 18.50 & 144.68 \\
\hline & E. acoroides & 3 & $X$ & 68.04 & 24.74 & 85.73 & 2.96 & 181.47 \\
\hline & $(n=3)$ & & $\mathrm{Sd}$ & 61.99 & 21.87 & 78.11 & 3.18 & 165.14 \\
\hline & C. rotundata & 8 & $X$ & 3.97 & 7.89 & 9.74 & 3.09 & 24.68 \\
\hline & $(n=8)$ & & $\mathrm{Sd}$ & 3.51 & 7.37 & 8.16 & 2.95 & 21.99 \\
\hline & C. serrulata & 2 & $\mathrm{X}$ & 4.01 & 2.53 & 14.34 & 2.40 & 23.28 \\
\hline & $(n=2)$ & & $\mathrm{Sd}$ & 1.86 & 1.31 & 7.66 & 1.22 & 12.05 \\
\hline & H. uninervis & 2 & $\mathrm{X}$ & 5.13 & 2.20 & 6.78 & 0.46 & 14.57 \\
\hline & $(n=2)$ & & $\mathrm{Sd}$ & 3.97 & 1.77 & 5.35 & 0.22 & 11.31 \\
\hline & S. isoetifolium & 2 & $X$ & 1.29 & 0.93 & 2.11 & 2.55 & 6.88 \\
\hline & $(n=2)$ & & $\mathrm{Sd}$ & 0.91 & 0.52 & 1.24 & 1.65 & 4.32 \\
\hline \multirow{6}{*}{$\begin{array}{l}\text { South } 2 \\
(\mathrm{~N}=27)\end{array}$} & T. hemprichii & 26 & $X$ & 11.45 & 14.04 & 31.73 & 15.68 & 72.89 \\
\hline & $(n=26)$ & & $\mathrm{Sd}$ & 10.79 & 11.59 & 26.83 & 13.19 & 62.40 \\
\hline & E. acoroides & 2 & $\mathrm{X}$ & 36.11 & 13.93 & 97.81 & 24.81 & 172.66 \\
\hline & $(n=2)$ & & $\mathrm{Sd}$ & 27.00 & 1.02 & 74.53 & 31.47 & 134.02 \\
\hline & H. ovalis & 7 & $X$ & 0.50 & 0.38 & 0.45 & 0.38 & 1.72 \\
\hline & $(n=7)$ & & $\mathrm{Sd}$ & 0.44 & 0.31 & 0.28 & 0.33 & 1.37 \\
\hline \multirow{8}{*}{$\begin{array}{l}\text { South } 3 \\
(\mathrm{~N}=30)\end{array}$} & T. hemprichii & 30 & $X$ & 17.28 & 22.59 & 28.02 & 12.92 & 80.81 \\
\hline & $(n=30)$ & & $\mathrm{Sd}$ & 16.98 & 18.98 & 23.51 & 8.90 & 68.37 \\
\hline & E. acoroides & 6 & $\mathrm{X}$ & 83.44 & 30.45 & 113.78 & 72.69 & 300.37 \\
\hline & $(n=6)$ & & $\mathrm{Sd}$ & 31.86 & 22.00 & 45.06 & 49.63 & 148.54 \\
\hline & H. ovalis & 3 & $\mathrm{X}$ & 0.33 & 0.14 & 0.32 & 0.25 & 1.05 \\
\hline & $(n=3)$ & & $\mathrm{Sd}$ & 0.13 & 0.04 & 0.16 & 0.09 & 0.42 \\
\hline & C. rotundata & 2 & $X$ & 9.90 & 19.71 & 14.12 & 6.00 & 49.73 \\
\hline & $(n=2)$ & & $\mathrm{Sd}$ & 0.64 & 1.42 & 10.66 & 1.94 & 14.67 \\
\hline
\end{tabular}

Table 2. Seagrass carbon storage $\left(\mathrm{gC} / \mathrm{m}^{2} / \mathrm{day}\right)$ in Pari Island, Jakarta Bay, Indonesia

\begin{tabular}{|c|c|c|c|c|c|c|c|}
\hline Species & $\begin{array}{l}\text { Productivity } \\
\text { above ground }\end{array}$ & $\begin{array}{l}\text { Productivity } \\
\text { below ground }\end{array}$ & Absorption & $\begin{array}{c}\text { Herbivore } \\
\text { consumption }\end{array}$ & Litter & Discharge & Storage \\
\hline & $\left(\mathrm{gC} / \mathrm{m}^{2} / \mathrm{hr}\right)$ & $\left(\mathrm{gC} / \mathrm{m}^{2} / \mathrm{hr}\right)$ & $\left(\mathrm{gC} / \mathrm{m}^{2} / \mathrm{hr}\right)$ & $\left(\mathrm{gC} / \mathrm{m}^{2} / \mathrm{hr}\right)$ & $\left(\mathrm{gC} / \mathrm{m}^{2} / \mathrm{hr}\right)$ & $\left(\mathrm{gC} / \mathrm{m}^{2} / \mathrm{hr}\right)$ & $\left(\mathrm{gC} / \mathrm{m}^{2} / \mathrm{hr}\right)$ \\
\hline 1 & 2 & 3 & $\begin{array}{c}4 \\
(=2+3)\end{array}$ & 5 & 6 & $\begin{array}{c}7 \\
(=5+6)\end{array}$ & $\begin{array}{c}8 \\
(=4-7)\end{array}$ \\
\hline E. acoroides & 1.368 & 0.457 & 1.825 & 0.339 & 0.438 & 0.777 & 1.048 \\
\hline T. hemprichii & 1.235 & 0.192 & 1.427 & 0.265 & 0.490 & 0.756 & 0.671 \\
\hline C. rotundata & 0.313 & 0.076 & 0.388 & 0.072 & 0.123 & 0.195 & 0.193 \\
\hline C. serrulata & 0.029 & 0.065 & 0.094 & 0.018 & 0.033 & 0.050 & 0.044 \\
\hline H. uninervis & 0.014 & 0.035 & 0.049 & 0.009 & 0.012 & 0.021 & 0.028 \\
\hline S. isoetifolium & 0.027 & 0.028 & 0.055 & 0.010 & 0.004 & 0.014 & 0.040 \\
\hline H. ovalis & 0.002 & 0.005 & 0.007 & 0.001 & 0.000 & 0.001 & 0.006 \\
\hline
\end{tabular}




\section{Discussion}

Seve species out of 12 species of seagrass species found in Indonesian waters (Syukur 2015) were recorded on the coastal waters of Pari Island and they were commonly found in the Kepulauan Seribu Marine National Park (BTNLKpS 2014). While, compared with the number of species found in the seagrass ecosystems in some other coastal areas, such as the coast of Tanjung Luar Lombok Timur (9 species recorded, Syukur et al. 2011); Tanjung Lesung Teluk Miskam Banten, (7 species recorded, Rustam et nal. 2013) and Kuta Bali beach (8 species recorded, Graha 2015), the diversity of seagrass species on coastal waters of Pari Island is categorized to be generally existed in other coastal waters of Indonesia. From the dominant species found in the coastal waters seagrass ecosystem of Pulau Pari and compared with the previously mentioned ecosystem, it can be seen that the diversity and dominant of seagrass species are not similar. It is strongly influenced by various environmental factors in the ecosystem, such as the type of substrate, sunlight intensity, water depth and water current velocity. As well as seagrass species found in other coastal ecosystems in Indonesia, on Pari Island the Enhalus, Thalassia, Syringodium and Halophila are easily found in the upper sublitoral and intertidal (Bengen 2004) with less than 5-10 m water depth.

Based on data of covering level on each plot, $T$. hemprichii (699 individuals $/ \mathrm{m}^{2}$ ) was estimated to have the highest density and followed by $C$. rotundata (344 individuals $/ \mathrm{m}^{2}$ ), the lowest density was $C$. serrulata and $H$. uninervis (80 individuals $/ \mathrm{m}^{2}$ ). Different from the seagrass ecosystems on coastal water of Sanur Bali, where $H$. uninervis and $S$. isoetifolium were the species with the highest covering (2189 individuals $/ \mathrm{m}^{2}$ and 1660 individuals $/ \mathrm{m}^{2}$ ) and the lowest was C. serrulata (35 individuals $/ \mathrm{m}^{2}$ ). Density conditions of each seagrass ecosystem would provide carbon storage data at each site, where the type and density of each species were important. Liberatus (2016) and Björk et al. (2008) explained that not only the species and its covering but also the storage of organic carbon was affected by the productivity of seagrass and its carbon sequestration capability. Nevertheless, Graha (2015) showed that seagrass ecosystem stored carbon more in the root and rhizome than on the substrate itself.

The seven species of seagrass with their sequestration capability showed that total seagrass carbon storage on Pari Island was influenced by the species with the largest carbon storage capability (E. acroides and T. hemprichii). This was because $E$. acroides had a high biomass because of its large morphological size, whereas $T$. hemprichii had a high biomass value because it was distributed widespread on the area of Pari Island. These results were similar to Graha (2015) about the species E. acroides and Liberatus (2016), Björk et al. (2008) about the productivity of each seagrass species (Table 2).

The carbon sequestration capability of seagrass on Pari Island contributed to the importance of seaweed as a world carbon storage (blue carbon) especially for the tropical area that contributed between $0.23-346.10 \mathrm{gC} / \mathrm{m}^{2}$ of carbon sequestration capabilities of the world's seagrass ecosystem
(1.684-110.819 $\left.\mathrm{gC} / \mathrm{m}^{2}\right)$. This showed that seagrass in the tropical area are good climate change mitigation agents (Liberatus 2016).

Seven seagrass species were found on the seagrass ecosystem in the coastal waters of Pari Island with $T$. hemprichii as a most dominant species. Carbon storage capacity ranged from $0.006-1.048 \mathrm{gC} / \mathrm{m}^{2} /$ day, depended on species and species abundance (density). The ability to store carbon on the coastal water of Pulau Pari, Jakarta Bay ranged between $0.23-346.10 \mathrm{gC} / \mathrm{m}^{2}$ and was dominantly stored in the root, rhizomes and dead organs of seagrass lies in its substrate.

\section{ACKNOWLEDGEMENTS}

We would like to express our utmost gratitude to the National Education Scholarship - Kemendikbud RI, Study program of environmental sciences graduate school of Padjadjaran University, Head of Oceanography Research Centre, LIPI, and Head of UPT LPKSDMO, Pari Island, LIPI, Jakarta, Indonesia and Head of Environmental Nonlitigation Dispute Settlement in Industry, Infrastructure, and Services (PSLH LPIPJ), Ministry of Environment and Forestry, Jakarta, Indonesia for their assistance in the course of this study.

\section{REFERENCES}

Aurora M. Ricart, Paul H. York, Michael A. Rasheed, Marta Pérez, Javier Romero, Catherine V. Bryant, Peter I. Macreadie. 2015. Variability of Sedimentary Organic Carbon In Patchy Seagrass Landscapes. Mar Poll Bull. DOI: 10.1016/j.marpolbul.2015.09.032.

Azkab MH. 1999. Guidelines for Seagrass Inventory. Oseana 24 (1): 1-16. Bengen DG. 2004. Technical Guidelines for Introduction and Management of Mangrove Ecosystems. The Center for Coastal Resources Studies and Oceans. Bogor Agricultural Institute. Bogor.

Björk M, Short F, McLeod E, Beer S. 2008. Managing Seagrasses for Resilience to Climate Change. IUCN. Gland.

Fourqurean JW, Duarte CM, Kennedy H, Marbà N, Holmer M, Mateo MA, Apostolaki ET, Kendrick GA, Jensen DK, McGlathery KJ, Serrano O. 2012. Seagrass Ecosystems as A Globally Significant Carbon Stock. Nature Geosci 5: 505-509.

Gattuso JP, Frankignoulle M, Wollast R. 1998. Carbon and Carbonate Metabolism in Coastal Aquatic Ecosystems. Ann Rev Ecol Syst 29: 405-434.

Graha YI. 2015. Deposit Carbon Seagrass In Sanur Beach Area, Denpasar City, [Thesis]. Postgraduate program, Udayana University. Denpasar.

Kiswara W. 1999. Development of Seagrass Ecosystem Research in Indonesia. Proceedings of Oceanology and Marine Environtment Sciences Seminar. Award to Prof. Dr. Aprilani Soegiarto, M.Sc. 1999. Jakarta, Indonesia. Oseanology LIPI. Jakarta. 181-197.

Kiswara W. 2010. Preliminary study: seagrass potential as carbon rosot and carbon sequestration on Pari Island Teluk Jakarta. Oseanol Limnol Indon 36 (3): 361-376. [Indonesian]

Mazarrasa I, Marbà N, Lovelock C E, Serrano O, Lavery P S, Fourqurean J W, Kennedy H, Mateo M A, Krause-Jensen D, Steven A D L, Duarte C M. 2015. Seagrass Meadows as A Globally Significant Carbonate Reservoir. Biogeosciences 12: 4993-5003.

Nienhuis PH, Coosen J, Kiswara W. 1989. Community stucture and biomass distribution of seagrasses and macrofauna in the Flores Sea, Indonesia. Neth J Sea Res 23 (2): 197-214.

Rahmawati S, Kiswara W. 2012. Carbon Reserve and Its Capacity as Carbon Storage on Single Vegetation Enhalus acoroides on Pari Island, Jakarta. Oseanol Limnol Indon 38 (1): 143-150. [Indonesian] 
Rahmawati S. 2011. Estimation of crabon reserves at seagrass community on Pari Island, Kepulauan Seribu National Park, Jakarta. J Segara 7 (1): 65-71. [Indonesian]

Rustam A, Kepel TL, Afiati RN, Salim HL, Astrid M, Daulat A, Mangindaan P, Sudirman N, Puspitaningsih Y, Dwiyanti D Hutahaean A. 2013. The Role of Seagrass as Blue Carbon in Climate Change Mitigation, Case Study of Tanjung Lesung, Banten. [research report] Center for Research and Development of Coastal Resources \& Marine, Balitbang Marine And Fisheries, Ministry of Marine Affairs and Fisheries. Jakarta. [Indonesian]

Schummacer BA. 2002. Methods for the Determination of Total Organic Carbon (TOC) in Soils and Sediments. Ecological Risk Assesment Support Centre. US EPA, Washington DC.
Silviani. 2011. Seagrass Mapping Using Alos Satellite Images on Pulau Pari Waters. [Hon. Thesis]. Faculty of Fisheries and Marine Science. Bogor Agricultural Institute. Bogor.

Sulaeman, Suparto, Eviati. 2005. Technical Guidance for Analysis on Soil, Water and Fertilizers. Indonesian Soil Research Institute, Agricultural Research and Development Agency, Ministry of Agriculture. Bogor.

Syukur A, Wardianto Y, Muchsin I, Kamal MM. 2011. Diversity and conditions of seagrass species on Tanjung Luar Coastal Waters of Lombok Timur. Biologi Tropica 12 (2): 92-99.

Tomasko D, Crooks S, Doug Robison D. 2012. Refining Carbon Sequestration Estimates of Seagrass Meadows In Tampa Bay. Proceedings, Tampa Bay Area Scientific Information Symposium, BASIS 6: 28-30 September 2015. St. Petersburg, Russia. 